\title{
The association between metabolic syndrome and the risk of prostate cancer, high-grade prostate cancer, advanced prostate cancer, prostate cancer-specific mortality and biochemical recurrence
}

Yu-zhu Xiang ${ }^{\dagger}$, Hui Xiong ${ }^{\dagger}$, Zi-lian Cui, Shao-bo Jiang, Qing-hua Xia, Yong Zhao, Guan-bin Li and Xun-bo Jin*

\begin{abstract}
Background: Although a previous meta-analysis reported no association between metabolic syndrome (MetS) and prostate cancer risk, a number of studies suggest that MetS may be associated with the aggressiveness and progression of prostate cancer. However, these results have been inconsistent. This systematic review and metaanalysis investigated the nature of this association.
\end{abstract}

Methods: We systematically searched MEDLINE, EMBASE and bibliographies of retrieved studies up to January 2013 using the keywords "metabolic syndrome" and "prostate cancer". We assessed relative risks (RRs) of the prostate cancer, several parameters of prostate cancer aggressiveness and progression associated with MetS using 95\% confidence intervals (95\% Cls).

Results: The literature search produced 547 hits from which 19 papers were extracted for the meta-analysis. In cancer-free population with and without MetS, the combined adjusted RR $(95 \% \mathrm{Cl})$ of prostate cancer risk and prostate cancer-specific mortality in longitudinal cohort studies is $0.96(0.85 \sim 1.09)$ and $1.12(1.02 \sim 1.23)$ respectively. In the prostate cancer patients with and without MetS, the combined unadjusted OR (95\% Cl) of high grade Gleason prostate cancer is $1.44(1.20 \sim 1.72)$, the OR of advanced prostate cancer is $1.37(1.12 \sim 1.68)$ and the OR of biochemical recurrence is $2.06(1.43 \sim 2.96)$.

Conclusions: The overall analyses revealed no association between MetS and prostate cancer risk, although men with MetS appear more likely to have high-grade prostate cancer and more advanced disease, were at greater risk of progression after radical prostatectomy and were more likely to suffer prostate cancer-specific death. Further primary studies with adjustment for appropriate confounders and larger, prospective, multicenter investigations are required.

Keywords: Gleason score, Recurrence, Clinical stage, Aggressiveness

\footnotetext{
* Correspondence: jinxunbo@163.com

${ }^{\dagger}$ Equal contributors

Minimally Invasive Urology Center, Provincial Hospital Affiliated to Shandong University, Jinan 250021, China
}

\section{Biomed Central}

(c) 2013 Xiang et al.; licensee BioMed Central Ltd. This is an Open Access article distributed under the terms of the Creative Commons Attribution License (http://creativecommons.org/licenses/by/2.0), which permits unrestricted use, distribution, and reproduction in any medium, provided the original work is properly cited. 


\section{Background}

In men, prostate cancer (PCa) is the most frequently diagnosed malignancy in industrialized countries [1] and it is the second most commonly diagnosed cancer and the sixth leading cause of cancer death worldwide [2]. There is a clear need for a better understanding of the risk factors related to $\mathrm{PCa}$ development and progression. Age, race and family history are the only established prostate cancer risk factors and these factors are all nonmodifiable. Recently, modifiable lifestyle factors such as physical activity and diet have been investigated. Because a higher incidence of $\mathrm{PCa}$ was associated with a higher prevalence of "western" lifestyle, it has been suggested that these lifestyle factors play a significant role in the pathogenesis of $\mathrm{PCa}$ [3].

Metabolic syndrome (MetS) is a cluster of cardiovascular risk factors that includes hypertension, diabetes mellitus, obesity, hypertriglyceridemia, and low highdensity lipoprotein cholesterol, with insulin resistance as the underlying hallmark feature [4]. The prevalence of MetS has been increasing worldwide and has become a major public health problem in many western countries. For example, $35 \%-41 \%$ of adults in the USA are reported to exhibit MetS [5]. Recently, increasing evidences suggests that MetS may be involved in the development and progression of certain types of cancer as an independent etiologic factor including breast cancer [6], endometrial cancer [7], colorectal cancer [8], pancreatic cancer [9] and prostate cancer [10]. MetS was firstly observed as a composite factor associated with prostate cancer risk in 2004 [11], and more studies have since reported the association between MetS and prostate cancer. However, the studies investigating the association between MetS and prostate cancer risk have reported inconsistent findings [12-21].

It is crucial to review and evaluate the magnitude to which MetS affects the development and progression of $\mathrm{PCa}$, as proper management of this modifiable lifestyle factor may help improve PCa outcomes.

A recently performed meta-analysis study summarized the association between MetS and the incidence of some common cancer types, including prostate cancer. The results, based on 14 databases, revealed that MetS was not associated with prostate cancer risk [22]. However, a new investigation on MetS and prostate cancer risk was published recently [19], and much increasing evidence in the latest investigations suggests that MetS may be associated with the aggressiveness and progression of $\mathrm{PCa}$; prostate cancer patients with MetS may suffer more aggressive disease and adverse clinical outcomes [19,23-27]. However, inverse results [28] or no significant associations $[14,20,29,30]$ have been reported in other studies. Therefore, to thoroughly investigate the nature of this association, we focused on longitudinal cohort studies and conducted a new meta-analysis to confirm the association between MetS and prostate cancer risk by searching the latest literature. Subsequently, we performed another meta-analysis to quantitatively summarize several parameters of PCa aggressiveness and progression, including Gleason score, clinical stage, biochemical recurrence and prostate cancer-specific mortality associated with MetS.

\section{Methods}

\section{Search strategy}

We systematically searched MEDLINE, EMBASE through January 2013 for human studies on the association between MetS and PCa with the following medical subject heading terms and/or text words: "metabolic syndrome", "insulin resistance syndrome", or "syndrome X", combined with "prostate cancer", "prostatic cancer", "prostate neoplasm", or "prostatic neoplasm". We also manually searched relevant journals, bibliographies, and reviews for additional articles. The search had no language restriction.

\section{Inclusion criteria}

The eligibility of each study was assessed independently by two investigators (YX and HX). We included only cohort studies of MetS and prostate cancer risk or prostate cancer-specific mortality and clinical studies of MetS and Gleason score or clinical stage at diagnosis or biochemical recurrence after treatment. We included studies that reported standardized forms of relative risk, risk ratio, hazard ratio or odds ratio with estimates of confidence intervals (CIs) or with sufficient data to estimate CIs. We used relative risks (RRs) to represent various effect estimates in a cohort study in this meta-analysis.

\section{Exclusion criteria}

We excluded reviews, editorials, meta-analysis and animal studies. Among the 23 studies that underwent full-text reviews, we excluded a study on MetS and prostate cancer risk of re-biopsy [31], a study that did not use a standard definition of MetS [32,33] and one case-control study on MetS and prostate cancer risk [21]. For studies previously published on the same database $[34,35]$, we included only the most recent findings $[19,20]$. All of the studies on which we focused reported RRs with 95\% CIs or sufficient data to estimate them.

\section{Data extraction}

The data extracted included publication data (the first author's last name, year of publication, and country of the population studied), study design, population resources, number of cases, risk estimates with their corresponding CIs, and variables controlled for by matching or in the most adjusted model. Abstractions of the data elements 
were conducted separately by two authors; discordant results were resolved by consensus.

\section{Statistical analysis}

Firstly, we updated the data and attempted to analyze the association of MetS with the prostate cancer risk in longitudinal cohort studies only. Subsequently, we assessed the association between MetS and prostate cancer-specific mortaligy in cohort studies and between MetS and high grade Gleason PCa and/or advanced PCa or biochemical recurrence in clinical studies. We pooled all of the RRs for MetS and assessed the heterogeneity between the studies by $\mathrm{Q}$ and $\mathrm{I}^{2}$ statistics, which are distributed as $\mathrm{x}^{2}$ statistics [36]. A value of $\mathrm{P}<0.10$ was used to indicate lack of homogeneity (heterogeneity) among effects. We used a fixed-effects model if $\mathrm{I}^{2}$ value significance was $<0.1$; otherwise, we used a random-effect model. Sensitivity analysis was conducted by omitting one study at a time, generating the pooled estimates and comparing with the original estimates. Funnel plots and both Begg's and Egger's tests were used to evaluate publication bias. All analyses were performed using STATA version 9.0 statistical software (Stata, College Station, Texas, USA). All statistical comparisons were 2 -sided, and a p-value $<0.05$ was considered statistically significant).

\section{Results}

\section{Study characteristics}

Nineteen studies met the search inclusion and exclusion criteria. The characteristics of included studies are presented in Tables 1 and 2.

Detailed search steps are described in Figure 1. Briefly, from the initial literature search we identified 547 abstracts. Twenty-three articles were considered of interest and full text of each article was retrieved for detailed evaluation. Eleven studies investigated the association between MetS and prostate cancer [11-21]. Nine of them were longitudinal cohort studies that reported the RRs of PCa in cancer-free population with and without MetS [7-15]. Seven studies evaluated MetS and pathological and clinical stages of $\mathrm{PCa}$, of these studies, 7/7 investigate Gleason score [20,23-26,28,29] and 4/7 investigated clinical stage $[20,23,24,29]$. Two case-control studies explored biochemical recurrence after primary treatment $[23,27]$, and three longitudinal cohort studies focused on prostate cancer-specific mortality $[14,19,30]$.

\section{Main findings}

\section{Prostate cancer risk}

Result from a meta-analysis based on nine longitudinal cohort studies revealed that there was no association between MetS and prostate cancer risk ( $R R=0.96,95 \%$ CI 0.85-1.09 $\mathrm{n}=9$ studies) (Figure 2).

\section{Prostate cancer aggressiveness}

High grade Gleason score The definition of high grade Gleason score is $\geq 7$ or $>7$. A trend for a $36 \%$ increased risk of a high Gleason score in patients with MetS $(\mathrm{OR}=1.36,95 \% \mathrm{CI} 0.90-2.06 \mathrm{n}=7$ studies $)$ was identified based on a meta-analysis of seven total relative databases (Figure 3).

Advanced clinical stage Advanced clinical stage was defined as a clinical stage $\geq$ T3. Four databases were included in the analysis of the association of MetS with advanced clinical stage. The analysis revealed that MetS was significantly associated with a $37 \%$ increased risk of advanced clinical stage $(\mathrm{OR}=1.37,95 \% \mathrm{CI}: 1.12 \sim 1.68$; $\mathrm{n}=4$ studies) (Figure 4 ).

\section{Prostate cancer progression}

Biochemical recurrence Only two databases [23,27] focused on the association of MetS which biochemical recurrence. The Individual study results and the overall summary results are presented in Figure 5. The result indicates that MetS was significantly associated with 2 -folds of increased risk of biochemical recurrence ( $\mathrm{OR}=2.06,95 \% \mathrm{CI}: 1.43-2.96, \mathrm{n}=2$ studies $)$.

Prostate cancer-specific mortality Three cohort studies $[14,19,30]$ investigated how MetS affected prostate cancer-specific mortality. The meta-analysis revealed that MetS was significantly associated with a higher risk of the prostate cancer-specific death ( $R R=1.12,95 \%$ CI: $1.02 \sim 1.23 ; \mathrm{n}=3$ studies) (Figure 6).

\section{Sensitivity analysis}

We conducted sensitivity analysis by omitting one study at a time, generating the pooled estimates and comparing the pooled estimates with the original estimates. Omitting any one of nine studies concerning MetS and prostate cancer risk or omitting any one of four studies concerning MetS and advanced clinical stage produced no dramatic influence on the original pooled RRs. Omitting Jeon 2012 database [28] in the 7 studies concerning MetS and Gleason score produced a significant $\mathrm{OR}=1.44 \quad(95 \% \mathrm{CI}: 1.20 \sim 1.72$ ), whereas none of the remaining severn studies exhibited a significant influence on the original estimates. For biochemical recurrence and prostate cancerspecific mortality, there were too few studies to do a sensitivity analysis.

\section{Publication bias}

Visual inspection of the Begg funnel plot for both PCR and Gleason score did not reveal the asymmetry typically associated with publication bias (Figure 7). Evidence of 
Table 1 Characteristics of cohort studies of metabolic syndrome and prostate cancer risk

\begin{tabular}{|c|c|c|c|c|c|c|c|c|c|c|c|}
\hline Author yr (ref. no.) & Country & Population & Mean age, yr & $\begin{array}{l}\text { Mean FU } \\
\text { time, yr }\end{array}$ & $\begin{array}{l}\text { Time } \\
\text { period }\end{array}$ & Cohort size & Definition of MetS & $\begin{array}{l}\text { No. of } \\
\text { cases }\end{array}$ & RRs & $95 \% \mathrm{Cl}$ & $\begin{array}{c}\text { Controlled } \\
\text { variables }\end{array}$ \\
\hline Laukkanen 2004 [11] & Finland & Kuopio communities & 52.6 & 15 & 1984-2001 & 1,880 & WHO & 56 & RR 1.90 & $1.1-3.5$ & Age \\
\hline Tande 2006 [12] & United States & $\begin{array}{l}\text { ARIC* (49\% white, } \\
51 \% \text { African American) }\end{array}$ & $45-64$ & 12.1 & $1987-2000$ & 6,429 & NCEP-ATP-III & 385 & RR 0.77 & $0.60-0.98$ & Age, race \\
\hline Russo 2008 [13] & Italy & $\begin{array}{l}\text { A pharmacologically } \\
\text { based diagnosis }\end{array}$ & 40 & 2.7 & 1999-2005 & NA & A pharmacologically based diagnosis & 94 & RR 0.93 & $0.75-1.14$ & Age \\
\hline Martin 2009 [14] & Norway & HUNT2 & $48 \pm 16.4$ & 9.3 & $1996-2005$ & 29,364 & NCEP-ATP-III & 687 & RR 0.91 & $0.77-1.09$ & Age+ \\
\hline Inoue 2009 [15] & Japan & Japan PHC population & $40-69$ & 10.2 & 1993-2004 & 9,548 & IDF & 119 & HR 0.76 & $0.47-1.22$ & Age+ \\
\hline \multirow[t]{2}{*}{ Grundmark 2010 [16] } & \multirow[t]{2}{*}{ Sweden } & \multirow[t]{2}{*}{ ULSAM } & \multirow[t]{2}{*}{50} & \multirow[t]{2}{*}{30.3} & \multirow[t]{2}{*}{ 1970-2003 } & 2,183 & NCEP-ATP-III & 226 & RR 1.29 & $0.89-1.88$ & \multirow[t]{2}{*}{ Age } \\
\hline & & & & & & 2,287 & IDF & 234 & RR 1.18 & $0.81-1.71$ & \\
\hline Wallner 2010 [17] & United States & Olmsted County & $40-79$ & 15 & 1990-NA & 2,445 & WHO & 206 & HR 0.65 & $0.37-1.10$ & Age \\
\hline \multirow[t]{2}{*}{ Osaki 2011 [18] } & \multirow[t]{2}{*}{ Japan } & \multirow{2}{*}{$\begin{array}{l}\text { The population-based } \\
\text { cancer registry }\end{array}$} & \multirow[t]{2}{*}{$60.5 \pm 10.8$} & \multirow[t]{2}{*}{9.3} & \multirow[t]{2}{*}{ 1992-2007 } & 8,239 & NCEP-ATP-III & 152 & HR 1.37 & $0.91-2.06$ & \multirow[t]{2}{*}{ Age } \\
\hline & & & & & & 8,239 & IDF & 152 & HR 1.18 & $0.74-1.90$ & \\
\hline \multirow[t]{3}{*}{ Häggström 2012 [19] } & Norway & Me-Can & 44 & 12 & NA & 289,866 & Upper quartile levels ATP-III criteria & 6,922 & RR 0.96 & $0.92-1.00$ & Age+ \\
\hline & Sweden & & & & & & & & & & \\
\hline & Austria & & & & & & & & & & \\
\hline
\end{tabular}

MetS = metabolic syndrome; $P C a=$ prostate cancer; $R R s=$ Relative risks; $C l=$ confidence interval; $A g e+=$ At least age; $W H O=$ World Health Organization;

NCEP-ATP-III = National Cholesterol Education Program Adult Treatment Panel III; IDF = International Diabetes Federation; HUNT $2=$ Nord-Trondelang

Health Study; $A R I C=$ Atherosclerosis Risk in Communities; $O R=$ odds ratio; *We use White-American data. 
Table 2 Characteristics of studies of metabolic syndrome and parameters of prostate cancer

\begin{tabular}{|c|c|c|c|c|c|c|c|c|c|c|}
\hline Author yr (ref. no.) & Country & Study design & Population & Mean age,yr & Time period & Definition Vof MetS & $\begin{array}{l}\text { No. of } \\
\text { cases }\end{array}$ & Outcomes & RRs & $95 \% \mathrm{Cl}$ \\
\hline \multirow[t]{2}{*}{ B.K 2007 [29] } & \multirow[t]{2}{*}{ Korea } & \multirow{2}{*}{$\begin{array}{l}\text { Cross-section } \\
\text { study }\end{array}$} & \multirow{2}{*}{$\begin{array}{l}\text { Patients who underwent } \\
\text { radical retropubic prostatectomy }\end{array}$} & \multirow[t]{2}{*}{$64.8 \pm 6.2$} & \multirow[t]{2}{*}{$2004-2006$} & \multirow[t]{2}{*}{ NCEP-ATP-III } & \multirow[t]{2}{*}{261} & Gleason score $\geq 7(4+3)$ & 0.972 & $0.637-1.482$ \\
\hline & & & & & & & & Clinical stage $\geq \top 3$ & 0.991 & $0.532-1.846$ \\
\hline \multirow{2}{*}{$\begin{array}{l}\text { Beebe-Dimmer } \\
2009 \text { [20] }\end{array}$} & \multirow[t]{2}{*}{ United States } & \multirow{2}{*}{$\begin{array}{l}\text { Case-control } \\
\text { study }\end{array}$} & \multirow[t]{2}{*}{ GECAP } & \multirow[t]{2}{*}{62.3} & \multirow[t]{2}{*}{ 1999-2004 } & \multirow[t]{2}{*}{ NCEP-ATP-III } & \multirow[t]{2}{*}{637} & Gleason score $\geq 7(4+3)$ & 1.2 & $0.64-2.27$ \\
\hline & & & & & & & & Clinical stage $\geq \mathrm{T} 3$ & 1.17 & $0.55-2.51$ \\
\hline \multirow{2}{*}{$\begin{array}{l}\text { Castillejos-Molina } \\
2011 \text { [23] }\end{array}$} & \multirow[t]{2}{*}{ Mexico } & \multirow{2}{*}{$\begin{array}{l}\text { Case-control } \\
\text { study }\end{array}$} & \multirow{2}{*}{$\begin{array}{l}\text { Patients with PC who } \\
\text { underwent surgical treatment }\end{array}$} & \multirow[t]{2}{*}{$64.8 \pm 6.97$} & \multirow[t]{2}{*}{ 1990-2007 } & \multirow[t]{2}{*}{ WHO } & \multirow[t]{2}{*}{210} & Gleason score $>7$ & 3.346 & $1.144-9.791$ \\
\hline & & & & & & & & Clinical stage $\geq \mathrm{T} 3$ & 1.628 & $0.915-2.896$ \\
\hline \multirow{2}{*}{$\begin{array}{l}\text { Kheterpal } \\
2012[24]\end{array}$} & \multirow[t]{2}{*}{ United States } & \multirow{2}{*}{$\begin{array}{l}\text { Cross-section } \\
\text { study }\end{array}$} & \multirow{2}{*}{$\begin{array}{l}\text { Patients who underwent robot } \\
\text { assisted radical prostatectomy }\end{array}$} & \multirow[t]{2}{*}{$60.7 \pm 6.9$} & \multirow[t]{2}{*}{$2005-2008$} & \multirow[t]{2}{*}{ IDF } & \multirow[t]{2}{*}{2756} & Gleason score $\geq 7(4+3)$ & 1.328 & $0.978-1.802$ \\
\hline & & & & & & & & Clinical stage $\geq \top 3$ & 1.416 & $1.109-1.808$ \\
\hline \multirow{2}{*}{$\begin{array}{l}\text { De Nunzio } \\
2011[25]\end{array}$} & \multirow[t]{2}{*}{ Italy } & Cross-section & Patients who underwent & 69 & 2009-2011 & NCEP-ATP-III & 83 & Gleason score $\geq 7$ & 3.82 & $1.33-10.9$ \\
\hline & & & $\begin{array}{l}\text { prostate biopsy for PSA } \\
>4 \mathrm{ng} / \mathrm{ml} \text { or abnormal DRE }\end{array}$ & & & & & Clinical stage $\geq \mathrm{T} 3$ & NA & NA \\
\hline Jeon 2012 [28] & Korea & Cross-section & Patients who underwent & $68.86 \pm 8.95$ & $2003-2011$ & NCEP-ATP-III & 90 & Gleason score $\geq 7(4+3)$ & 0.101 & $0.022-0.473$ \\
\hline & & study & $\begin{array}{l}\text { prostate biopsy for PSA } \\
>4 \mathrm{ng} / \mathrm{ml} \text { or abnormal DRE }\end{array}$ & & & & & Clinical stage $\geq \top 3$ & NA & NA \\
\hline Morote 2012 [26] & Spain & Cross-section & Patients who underwent & $68(46-79)$ & $2006-2010$ & NCEP-ATP-III & 848 & Gleason score $>7$ & 1.75 & $1.260-2.414$ \\
\hline & & & $\begin{aligned} & \text { prostate biopsy for PSA } \\
> & 4 \mathrm{ng} / \mathrm{ml} \text { or abnormal DRE }\end{aligned}$ & & & & & Clinical stage $\geq \mathrm{T} 3$ & NA & NA \\
\hline $\begin{array}{l}\text { Castillejos-Molina } \\
2011 \text { [23] }\end{array}$ & Mexico & $\begin{array}{l}\text { Case-control } \\
\text { study }\end{array}$ & $\begin{array}{l}\text { Patients with } P C \text { who } \\
\text { underwent surgical treatment }\end{array}$ & $64.8 \pm 6.97$ & 1990-2007 & WHO & 210 & Biochemical recurrence & 2.73 & $1.65-4.50$ \\
\hline Post 2011 [27] & United States & $\begin{array}{l}\text { Case-control } \\
\text { study }\end{array}$ & $\begin{array}{l}\text { Patients who underwent } \\
\text { radical prostatectomy }\end{array}$ & 60.9 & 1999- 2004 & NCEP-ATP-III & 383 & Biochemical recurrence & 1.5 & $0.90-2.6$ \\
\hline $\begin{array}{l}\text { Jaggers } \\
2009[30]\end{array}$ & United States & Cohort study & $\begin{array}{l}\text { Aerobics Center } \\
\text { Longitudinal Study }\end{array}$ & $20-88$ & $1977-2003$ & NCEP-ATP-III & 185 & Mortality & 1.32 & $0.63-2.77$ \\
\hline Martin 2009 [14] & Norway & Cohort study & HUNT2 & $48 \pm 16.4$ & $1996-2005$ & NCEP-ATP-III & 107 & Mortality & 0.81 & $0.52-1.25$ \\
\hline $\begin{array}{l}\text { Häggström } \\
2012[19]\end{array}$ & $\begin{array}{c}\text { Norway Sweden } \\
\text { Austria }\end{array}$ & Cohort study & Me-Can & 44 & NA & $\begin{array}{l}\text { Upper quartile } \\
\text { Levels ATP-III criteria }\end{array}$ & 961 & Mortality & 1.13 & $1.03-1.25$ \\
\hline
\end{tabular}

$P C a=$ prostate cancer; $R R s=$ Relative risks; $C l=$ confidence interval; $W H O=$ World Health Organization; NCEP-ATP-III = National Cholesterol Education Program Adult Treatment Panel III; IDF = International Diabetes Federation; HUNT 2 = Nord-Trondelang Health Study; $N A=$ Not available; $D R E=$ Digital rectal examination. 


\begin{tabular}{|c|c|}
\hline 547 Potentially relevant articles identified from MEDLINE \& EMBASE & $\begin{array}{l}352 \text { Excluded } \\
219 \text { Review }\end{array}$ \\
\hline \multirow{2}{*}{$\boldsymbol{v}$} & 87 Abstract only \\
\hline & $\begin{array}{ll}33 & \text { Editorial } \\
9 & \text { Meta-analysis }\end{array}$ \\
\hline \multirow{2}{*}{195 Potentially relevant articles evaluated } & \multirow{4}{*}{$\begin{array}{l}172 \text { Excluded } \\
\text { Did not study MetS as exposure and prostate } \\
\text { cancer risk or parameters of prostate cancer } \\
\text { as outcome }\end{array}$} \\
\hline & \\
\hline & \\
\hline$\downarrow$ & \\
\hline 23 Evaluated in detail (full text) & \\
\hline $\boldsymbol{v}$ & $\begin{array}{l}1 \text { Study on MetS factors and prostate cancer } \\
\text { risk without a standard MetS definition. } \\
2 \text { Published previously on the same or subset of }\end{array}$ \\
\hline $\begin{array}{l}19 \text { Included in meta-analysis } \\
9 \text { Cohort studies on MetS and prostate cancer risk in prostate cancer- } \\
\text { free population } \\
7 \text { Studies on MetS and high grade Gleason prostate cancer } \\
4 \text { Studies on MetS and advanced prostate cancer } \\
2 \text { Studies on MetS and biochemical recurrence } \\
3 \text { Cohort studies on MetS and prostate cancer-specific mortality }\end{array}$ & $\begin{array}{l}1 \text { Study on MetS aand prostate cancer risk of } \\
\text { re-biopsy } \\
1 \text { Study on MetS factors and biochemical } \\
\text { recurrence without a standard MetS definition } \\
1 \text { Case-control study on MetS and prostate } \\
\text { cancer risk } \\
2 \text { Additional retrieved from bibliography }\end{array}$ \\
\hline
\end{tabular}

publication bias was also not seen with the Egger or Begg tests (Egger $\mathrm{P}=0.27$ and 0.64 for prostate cancer risk and Gleason score respectively).

\section{Discussion}

In 2007, Hsing et al. summarized five studies on MetS and prostate cancer risk and concluded that the epidemiologic evidence was insufficient to suggest a link between MetS and PCa [37]. In 2012, Esposito et al. performed a systematical review and meta-analysis on the association of MetS and cancer risk including prostate cancer. The authors also concluded that MetS was not associated with prostate cancer risk too [22]. In the present study, we updated the data and used the current evidence to analyze whether MetS is associated with prostate cancer risk. We observed the same result as previous meta-analysis; no

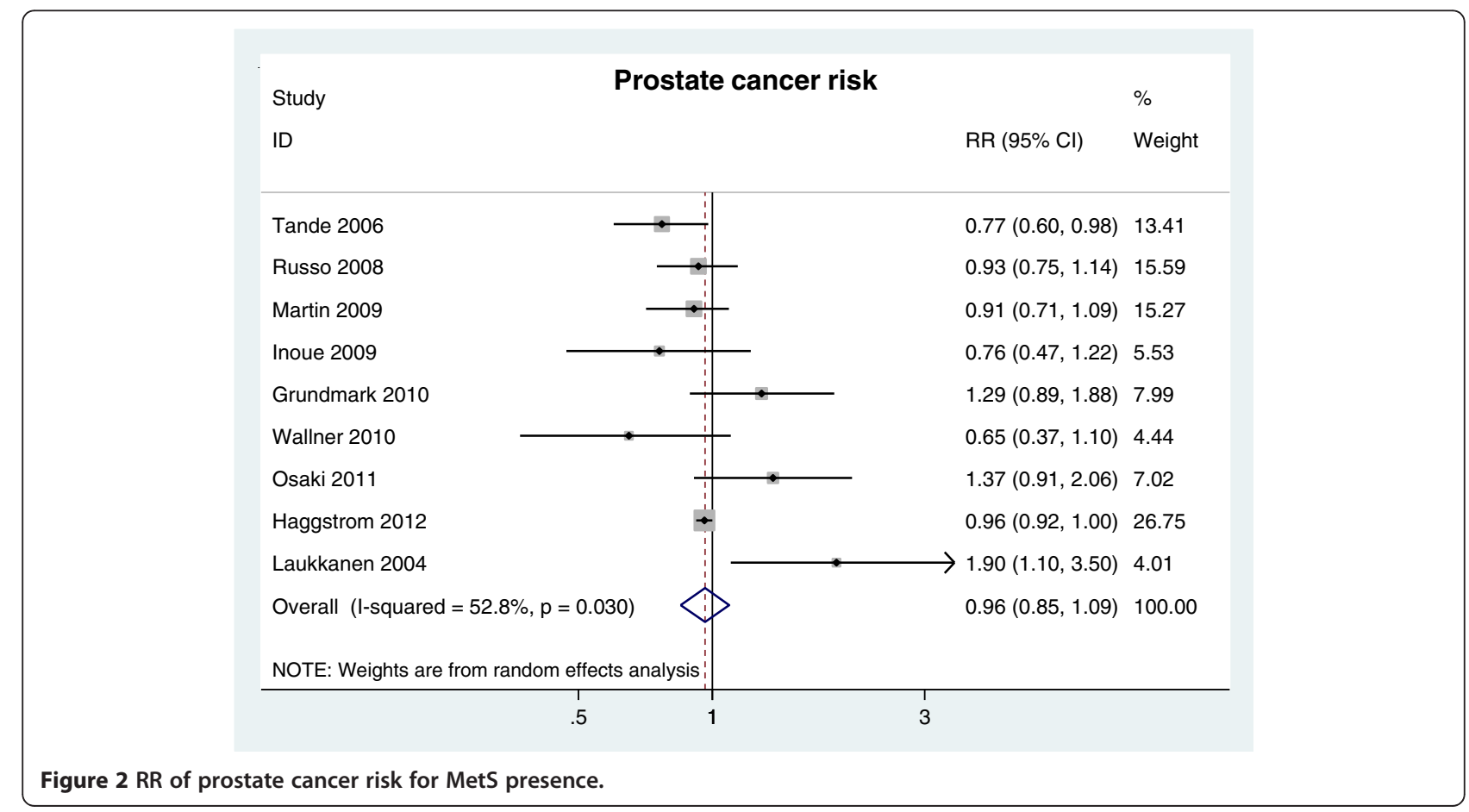




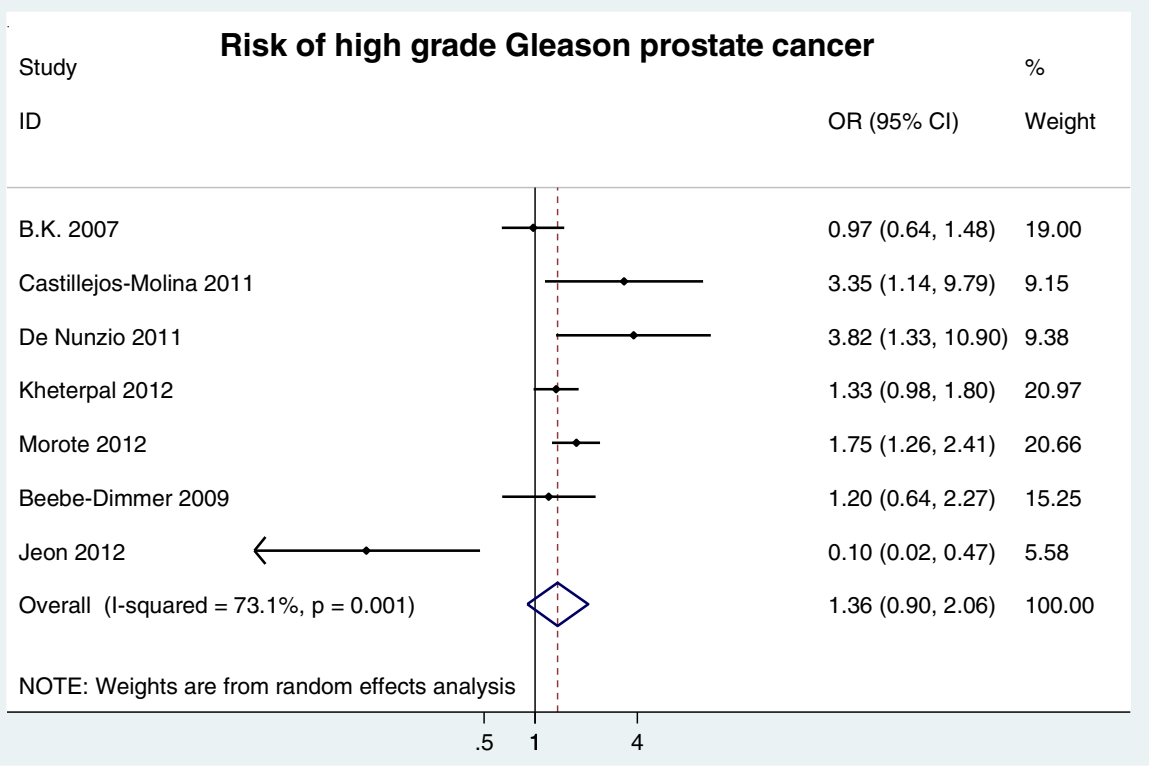

Figure 3 RR of high grade Gleason prostate cancer risk for MetS presence.

association could be detected between Mets and prostate cancer.

We believe the result is reliable for two reasons. Firstly, only longitudinal cohort studies were included in this analysis, imparting strong evidence for our conclusions. In addition, the association between MetS and prostate cancer may be affected by several factors, including heterogeneity among the individual studies. The heterogeneity may arise from differences in age, race, the definition of MetS [22], and geographic factors [26]. Further, MetS is a syndrome composed of at least 3 components, and the individual component may exert antagonistic functions on one another Thus the syndrome may represent an integrated outcome that combines neutralizing positive and negative functions. For example, a meta-analysis revealed that diabetes mellitus was significantly negatively associated with prostate cancer risk in population-based studies ( $R R=0.72,95 \%$ CI: 0.64-0.81) and cohort studies conducted in the USA ( $R R=0.79,95 \%$ CI: $0.73,0.86)$ [38]. Furthermore, several genome-wide association

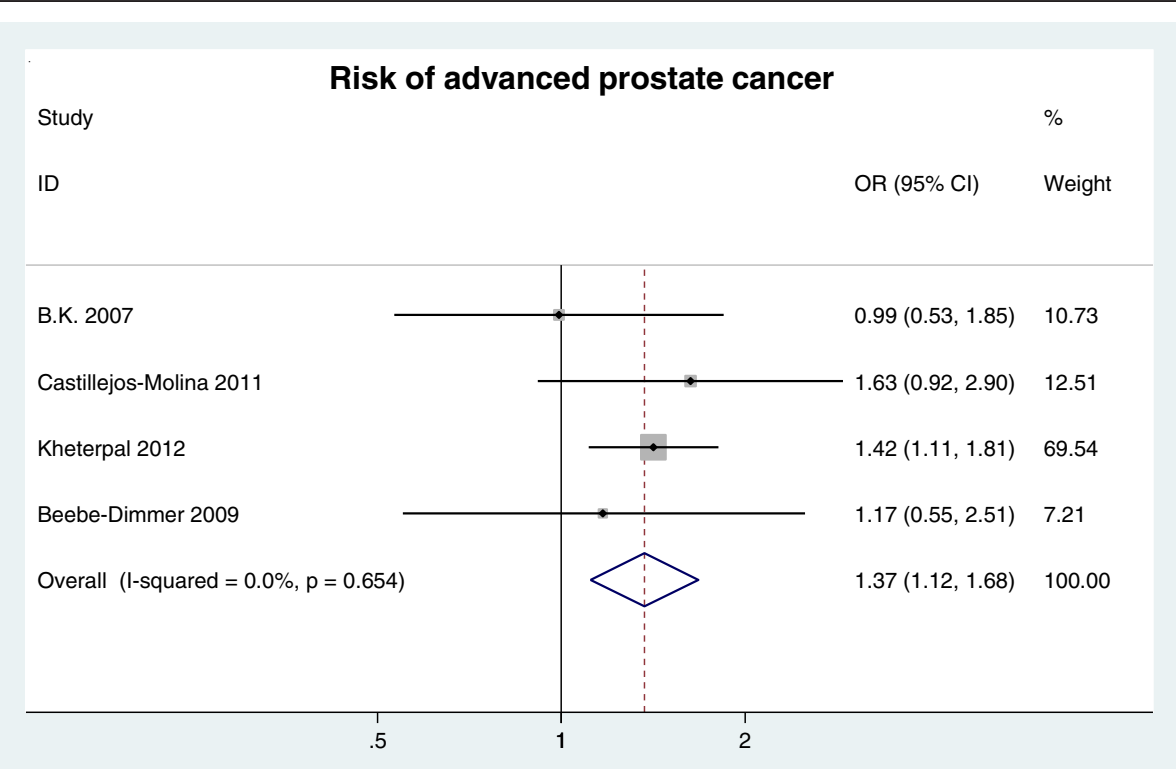

Figure 4 RR of advanced clinical stage for MetS presence. 


\section{Risk of biochemical recurrence}

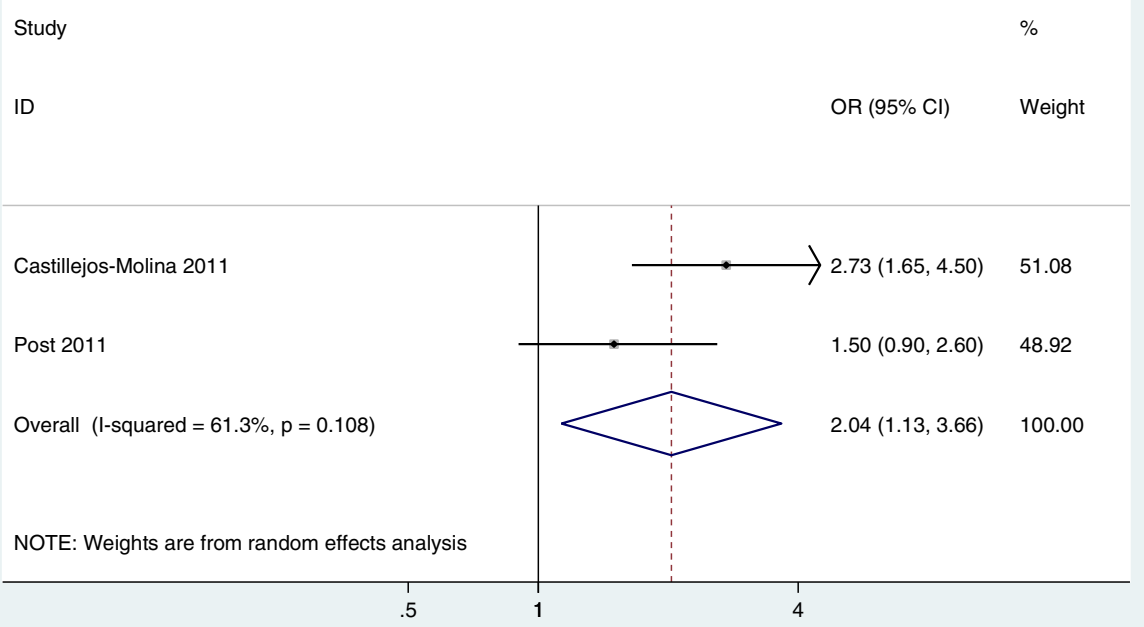

Figure 5 RR of biochemical recurrence for MetS presence.

studies suggest that diabetes mellitus and prostate cancer share certain genetic factors, including the $H N F 1 \beta$ and JAZF1 genes, and a previous study suggested that JAZF1 might represent a potential target against diabetes and obesity [39]. Although hypertension was found to be positively associated with prostate cancer risk [33,40-42], Obesity is negatively with localized prostate cancer $(0.94,95 \%$ CI, 0.91-0.97) and positively associated with advanced prostate cancer risk (1.07, 95\% CI 1.01-1.13) [43].
However, after analyses of several parameters of PCa aggressiveness and progression, we found MetS to be significantly associated with an increased risk of prostate cancer with a high-Gleason score or advanced clinical stage, with biochemical recurrence after primary treatment and with prostate cancer-specific mortality. If confirmed by more investigations, this finding may open a new research field on PCa development and progression, potentially leading to new strategies or methods for $\mathrm{PCa}$ treatment. MetS is a major public health problem

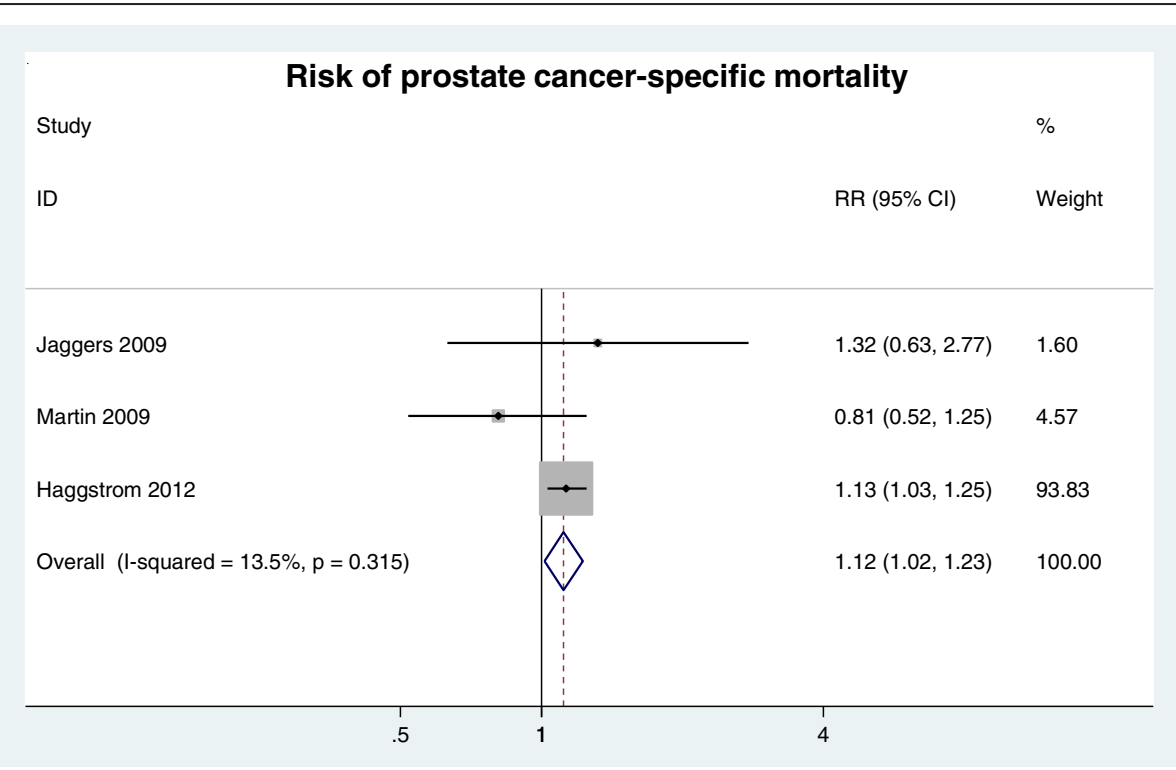

Figure 6 RR of prostate cancer-specific mortality for MetS presence. 

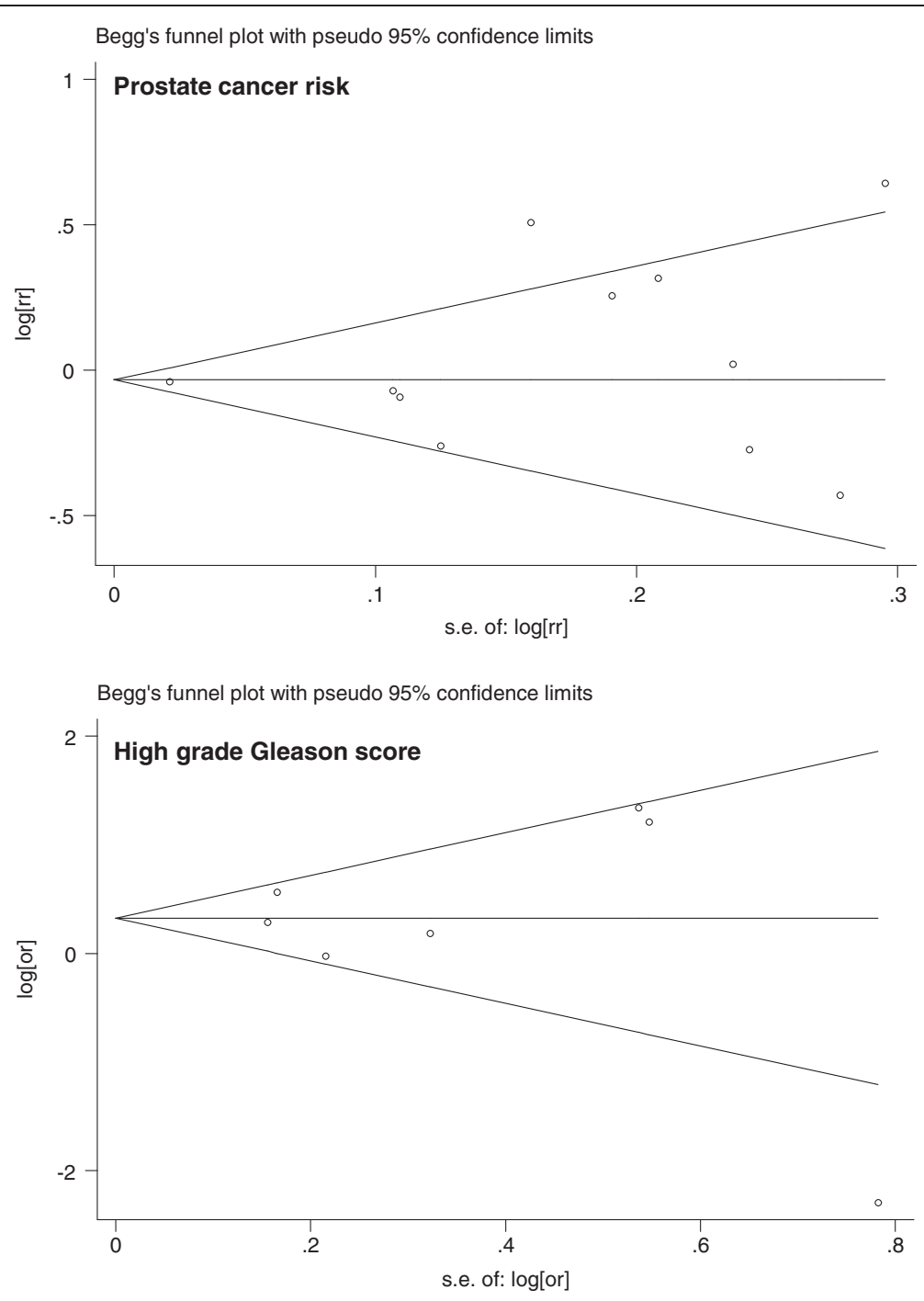

Figure 7 Funnel plot with pseudo $95 \%$ confidence limits.

and prostate cancer is the most prevalent solid organ tumor, accounts for $29 \%$ of all cancer cases and the second most common cause of death by cancer among men in the USA [44]. Therefore we believe that there is a compelling need to investigate this association between MetS and prostate cancer although the association is not strong.

Nevertheless, the reliability of these results is limited. First, Gleason score and clinical stage data were extracted from cross-sectional studies not longitudinal cohort studies. Second, there exists a small difference among studies on the definition of high-grade Gleason $\mathrm{PCa}$, some authors defined a high Gleason score $\geq 7$ whereas others defined a high score as $>7$. Third, the pathological stage data in some studies were from biopsy not radical prostatectomy specimens. Last but not least, to date there remains limited studies focusing on this association, although many of the available studies are well designed case-control or longitudinal cohort studies.

In addition to the limitations listed above, another limitation for the analyses of the association between MetS and prostate cancer risk or prostate cancer parameters is that we did not perform a meta-regression to attempt to explain the heterogeneity of the study because of the varying adjustments in the individual studies. The result of a recent meta-analysis on 9 crosssectional studies of metabolic syndrome in adult cancer survivors increases the weight of this suspicion, as it revealed that no significant association was found for nonhematologic malignancies, including testicular tumor, prostate cancer, sarcoma, and epithelial ovarian [45]. Therefore, there is an urgent future need to confirm this association and to find potential mechanisms to explain 
how metabolic factors affect the development or progression of $\mathrm{PCa}$.

\section{Conclusions}

Based on the current findings, MetS is not associated with prostate cancer risk, but preliminary evidences demonstrates that men with MetS more frequently suffer high-grade prostate cancer, more advanced disease and are at greater risk of progression after radical prostatectomy and prostate cancer-specific death. Together, these findings indicate that MetS may be associated with the progression of prostate cancer and adverse clinical outcomes. Further studies with adjustment for appropriate confounders and larger, prospective, multicenter investigations are required in the future.

\section{Abbreviations}

PCa: Prostate cancer; MetS: Metabolic syndrome; RR: Relative risk; OR: Odd ratio; HR: Hazard ratio; Cls: Confidence intervals.

\section{Competing interests}

No potential conflicts of interest were disclosed.

\section{Authors' contributions}

This study was designed and supervised by XJ. Literature search, selection and data extraction was by $Y X$ and $H X$, and data analyses were performed by $Y X, H X, Z C, S J, Q X, Y Z$ and GL. Data interpretation and manuscript writing received contributions from all authors. All authors read and approved the final manuscript.

\section{Acknowledgments}

The authors thank Dina A Yousif from department of Medcine, Vanderbilt University, USA for checking the English language of the manuscript.

\section{Funding}

This study was supported by China Scholarship Council (NO: 2009622110) and National Science Fund for Distinguished Young Scholars (NO: 81202016).

Received: 13 January 2013 Accepted: 8 February 2013

Published: 13 February 2013

\section{References}

1. Jemal A, Bray F, Center MM, Ferlay J, Ward E, Forman D: Global cancer statistics. CA Cancer J Clin 2011, 61(2):69-90.

2. Siegel R, Ward E, Brawley O, Jemal A: Cancer statistics, 2011: the impact of eliminating socioeconomic and racial disparities on premature cancer deaths. CA Cancer J Clin 2011, 61(4):212-236.

3. Nelson WG, De Marzo AM, Isaacs WB: Prostate cancer. N Engl J Med 2003, 349(4):366-381.

4. Reaven GM: Banting lecture 1988. Role of insulin resistance in human disease. Diabetes 1988, 37(12):1595-1607.

5. Alberti KG, Eckel RH, Grundy SM, Zimmet PZ, Cleeman Jl, Donato KA Fruchart JC, James WP, Loria CM, Smith SC Jr: Harmonizing the metabolic syndrome: a joint interim statement of the International Diabetes Federation Task Force on Epidemiology and Prevention; National Heart, Lung, and Blood Institute; American Heart Association; World Heart Federation; International Atherosclerosis Society; and International Association for the Study of Obesity. Circulation 2009, 120(16):1640-1645

6. Pothiwala P, Jain SK, Yaturu S: Metabolic syndrome and cancer. Metab Syndr Relat Disord 2009, 7(4):279-288.

7. Rosato V, Zucchetto A, Bosetti C, Dal Maso L, Montella M, Pelucchi C, Negri E, Franceschi S, La Vecchia C: Metabolic syndrome and endometrial cancer risk. Ann Oncol 2011, 22(4):884-889.

8. Pelucchi C, Negri E, Talamini R, Levi F, Giacosa A, Crispo A, Bidoli E, Montella $M$, Franceschi S, La Vecchia C: Metabolic syndrome is associated with colorectal cancer in men. Eur J Cancer 2010, 46(10):1866-1872.
9. Rosato V, Tavani A, Bosetti C, Pelucchi C, Talamini R, Polesel J, Serraino D, Negri E, La Vecchia C: Metabolic syndrome and pancreatic cancer risk: a case-control study in Italy and meta-analysis. Metabolism 2011, 60(10):1372-1378.

10. Zhou JR, Blackburn GL, Walker WA: Symposium introduction: metabolic syndrome and the onset of cancer. Am J Clin Nutr 2007, 86(3):s817-s819.

11. Laukkanen JA, Laaksonen DE, Niskanen L, Pukkala E, Hakkarainen A, Salonen JT: Metabolic syndrome and the risk of prostate cancer in Finnish men: a population-based study. Cancer Epidemiol Biomarkers Prev 2004 13(10):1646-1650.

12. Tande AJ, Platz EA, Folsom AR: The metabolic syndrome is associated with reduced risk of prostate cancer. Am J Epidemiol 2006, 164(11):1094-1102.

13. Russo A, Autelitano M, Bisanti L: Metabolic syndrome and cancer risk. Eur J Cancer 2008, 44(2):293-297.

14. Martin RM, Vatten L, Gunnell D, Romundstad P, Nilsen Tl: Components of the metabolic syndrome and risk of prostate cancer: the HUNT 2 cohort, Norway. Cancer Causes Control 2009, 20(7):1181-1192.

15. Inoue $M$, Noda M, Kurahashi N, Iwasaki M, Sasazuki S, Iso H, Tsugane S: Impact of metabolic factors on subsequent cancer risk: results from a large-scale population-based cohort study in Japan. Eur J Cancer Prev 2009, 18(3):240-247.

16. Grundmark B, Garmo H, Loda M, Busch C, Holmberg L, Zethelius B: The metabolic syndrome and the risk of prostate cancer under competing risks of death from other causes. Cancer Epidemiol Biomarkers Prev 2010, 19(8):2088-2096

17. Wallner LP, Morgenstern H, McGree ME, Jacobson DJ, St Sauver JL, Jacobsen SJ, Sarma AV: The effects of metabolic conditions on prostate cancer incidence over 15 years of follow-up: Results from the Olmsted County Study. BJU Int 2011, 107(6):929-935.

18. Osaki Y, Taniguchi S, Tahara A, Okamoto M, Kishimoto T: Metabolic syndrome and incidence of liver and breast cancers in Japan. Cancer Epidemiol 2012, 36(2):141-147.

19. Haggstrom C, Stocks T, Ulmert D, Bjorge T, Ulmer H, Hallmans G, Manjer J, Engeland A, Nagel G, Almqvist M, et al: Prospective study on metabolic factors and risk of prostate cancer. Cancer 2012, 118(24):6199-6206.

20. Beebe-Dimmer JL, Nock NL, Neslund-Dudas C, Rundle A, Bock CH, Tang D, Jankowski M, Rybicki BA: Racial differences in risk of prostate cancer associated with metabolic syndrome. Urology 2009, 74(1):185-190.

21. Pelucchi C, Serraino D, Negri E, Montella M, Dellanoce C, Talamini R, La Vecchia C: The metabolic syndrome and risk of prostate cancer in Italy. Ann Epidemiol 2011, 21(11):835-841.

22. Esposito K, Chiodini P, Colao A, Lenzi A, Giugliano D: Metabolic Syndrome and Risk of Cancer: A systematic review and meta-analysis. Diabetes Care 2012, 35(11):2402-2411.

23. Castillejos-Molina R, Rodriguez-Covarrubias F, Sotomayor M, GomezAlvarado MO, Villalobos-Gollas M, Gabilondo F, Feria-Bernal G: Impact of metabolic syndrome on biochemical recurrence of prostate cancer after radical prostatectomy. Urol Int 2011, 87(3):270-275.

24. Kheterpal E, Sammon JD, Diaz M, Bhandari A, Trinh QD, Pokala N, Sharma P, Menon M, Agarwal PK: Effect of metabolic syndrome on pathologic features of prostate cancer. Urol Oncol 2012, Epub ahead of print.

25. De Nunzio C, Freedland SJ, Miano R, Trucchi A, Cantiani A, Carluccini A, Tubaro A: Metabolic syndrome is associated with high grade gleason score when prostate cancer is diagnosed on biopsy. Prostate 2011, Epub ahead of print.

26. Morote J, Ropero J, Planas J, Bastaros JM, Delgado G, Placer J, Celma A, de Torres IM, Carles J, Reventos J, et al: Metabolic syndrome increases the risk of aggressive prostate cancer detection. BJU Int 2012, Epub ahead of print.

27. Post JM, Beebe-Dimmer JL, Morgenstern $\mathrm{H}$, Neslund-Dudas $\mathrm{C}$, Bock $\mathrm{CH}_{\text {, }}$ Nock N, Rundle A, Jankowski M, Rybicki BA: The Metabolic Syndrome and Biochemical Recurrence following Radical Prostatectomy. Prostate Cancer 2011, 2011:245642.

28. Jeon KP, Jeong TY, Lee SY, Hwang SW, Shin JH, Kim DS: Prostate cancer in patients with metabolic syndrome is associated with low grade Gleason score when diagnosed on biopsy. Korean J Urol 2012, 53(9):593-597.

29. B.K H: The characteristics of prostate cancer with metabolic syndrome in Korean men. Korean J Urol 2007, 48(6):585-591.

30. Jaggers JR, Sui X, Hooker SP, LaMonte MJ, Matthews CE, Hand GA, Blair SN: Metabolic syndrome and risk of cancer mortality in men. Eur J Cancer 2009, 45(10):1831-1838. 
31. Antonio C, Francesco C, Cosimo DN, Andrea T, Rocco D: Patients with metabolic syndrome and widespread high grade prostatic intraepithelial neoplasia are at a higher risk factor of prostate cancer on re-biopsy: a prospective single cohort study. Urol Oncol 2012, Epub ahead of print.

32. Hammarsten J, Hogstedt B: Hyperinsulinaemia: a prospective risk factor for lethal clinical prostate cancer. Eur J Cancer 2005, 41(18):2887-2895.

33. Asmar R, Beebe-Dimmer JL, Korgavkar K, Keele GR, Cooney KA: Hypertension, obesity and prostate cancer biochemical recurrence after radical prostatectomy. Prostate Cancer Prostatic Dis 2012, Epub ahead of print.

34. Lund Haheim L, Wisloff TF, Holme I, Nafstad P: Metabolic syndrome predicts prostate cancer in a cohort of middle-aged Norwegian men followed for 27 years. Am J Epidemiol 2006, 164(8):769-774.

35. Beebe-Dimmer JL, Dunn RL, Sarma AV, Montie JE, Cooney KA: Features of the metabolic syndrome and prostate cancer in African-American men. Cancer 2007, 109(5):875-881.

36. Higgins JP, Thompson SG: Quantifying heterogeneity in a meta-analysis. Stat Med 2002, 21(11):1539-1558.

37. Hsing AW, Sakoda LC, Chua S Jr: Obesity, metabolic syndrome, and prostate cancer. Am J Clin Nutr 2007, 86(3):S843-857.

38. Zhang F, Yang Y, Skrip L, Hu D, Wang Y, Wong C, Qiu J, Lei H: Diabetes mellitus and risk of prostate cancer: an updated meta-analysis based on 12 case-control and 25 cohort studies. Acta Diabetol 2012, Epub ahead of print.

39. Li L, Yang Y, Yang G, Lu C, Yang M, Liu H, Zong H: The role of JAZF1 on lipid metabolism and related genes in vitro. Metabolism 2011, 60(4):523-530.

40. Fitzpatrick AL, Daling JR, Furberg CD, Kronmal RA, Weissfeld JL: Hypertension, heart rate, use of antihypertensives, and incident prostate cancer. Ann Epidemiol 2001, 11(8):534-542.

41. Ganesh B, Saoba SL, Sarade MN, Pinjari SV: Risk factors for prostate cancer: An hospital-based case-control study from Mumbai, India. Indian I Urol 2011, 27(3):345-350.

42. Martin RM, Vatten L, Gunnell D, Romundstad P: Blood pressure and risk of prostate cancer: Cohort Norway (CONOR). Cancer Causes Control 2010, 21(3):463-472

43. Discacciati A, Orsini N, Wolk A: Body mass index and incidence of localized and advanced prostate cancer-a dose-response meta-analysis of prospective studies. Ann Oncol 2012, 23(7):1665-1671.

44. Siegel R, Naishadham D, Jemal A: CA Cancer J Clin 2012, 62(1):10-29.

45. Jung HS, Myung SK, Kim BS, Seo HG: Metabolic syndrome in adult cancer survivors: a meta-analysis. Diabetes Res Clin Pract 2012, 95(2):275-282.

doi:10.1186/1756-9966-32-9

Cite this article as: Xiang et al: The association between metabolic syndrome and the risk of prostate cancer, high-grade prostate cancer, advanced prostate cancer, prostate cancer-specific mortality and biochemical recurrence. Journal of Experimental \& Clinical Cancer Research 2013 32:9.

\section{Submit your next manuscript to BioMed Central and take full advantage of:}

- Convenient online submission

- Thorough peer review

- No space constraints or color figure charges

- Immediate publication on acceptance

- Inclusion in PubMed, CAS, Scopus and Google Scholar

- Research which is freely available for redistribution 